\title{
Membrane Engineering for Biogas Valorization
}

\author{
Adele Brunetti ${ }^{*}$ and Giuseppe Barbieri \\ National Research Council-Institute on Membrane Technology (ITM-CNR), Rende, Italy
}

Membrane operations nowadays drive the innovative design of important separation, conversion, and upgrading processes, and contribute to realizing the main principles of "green process engineering" in various sectors. In this perspective, we propose the redesign of traditional plants for biogas upgrading and integrating and/or replacing conventional operations with innovative membrane units. Bio-digester gas streams contain valuable products such as biomethane, volatile organic compounds, and volatile fatty acids, whose recovery has important advantages for environment protection, energy saving, and waste valorization. Advanced membrane units can valorize biogas by separating its various components, and establishing environmentally friendly and small-scale energivorous novel separation processes enables researchers to pursue the requirements of circular economy.

\section{OPEN ACCESS}

Edited by:

Eric Favre,

Université de Lorraine, France

Reviewed by:

Xuezhong He,

Guangdong Technion-Israel Institute of Technology (GTIIT), China

Giuseppe Genduso,

King Abdullah University of Science and Technology, Saudi Arabia

${ }^{*}$ Correspondence: Adele Brunetti a.brunetti@itm.cnr.it

Specialty section: This article was submitted to Separation Processes, a section of the journal Frontiers in Chemical Engineering

Received: 14 September 2021 Accepted: 11 October 2021 Published: 26 October 2021

Citation:

Brunetti A and Barbieri G (2021) Membrane Engineering for Biogas Valorization.

Front. Chem. Eng. 3:775788. doi: $10.3389 /$ fceng.2021.775788
Keywords: biomethane, VOCs, VFA, water recovery, pre-treatments, circular economy

\section{INTRODUCTION}

The use of renewable energies is increasing continuously to mitigate the increment of earth temperature. The International Renewable Energy Agency (IRENA) estimated that 65\% of global energy supply must utilize renewables sources by 2050 (IRENA, 2018; Kapoor et al., 2019). Among these, biogas plays a crucial role in the market of renewable energies because of its lower capital and operating costs, and the fact that a wide range of organic biomass wastes can be used to generate biogas, which otherwise would be landfilled and would increase greenhouse gas emissions (GHG). The power produced by biogas in Europe is estimated to increase from $14.5 \mathrm{GW}$ in 2012 to $29.5 \mathrm{GW}$ in 2022 (Maroneze et al., 2014; Kárászová et al., 2015).

Biogas is a product of waste valorization by means of a bio-digester. This aeriform downstream is a vapor-saturated stream containing $50-60 \% \mathrm{CH}_{4}, 30-40 \% \mathrm{CO}_{2}$ and, owing to its origin, various pollutants and contaminants such as particulate matter, acid and basic gases $\left(\mathrm{H}_{2} \mathrm{~S}, \mathrm{NH}_{3}\right.$, etc.), siloxanes, halides, volatile organic compounds (VOCs) (such as toluene, xylene, trichloro-ethylene, trichloro-ethane, ethylene glycol mono-ethyl ether, etc.), and volatile fatty acids (VFA) (Weiland, 2010). Biomethane obtained from biogas purification can be used in the replacement of fossil fuels in power and heat production and in transportation. However, the presence of contaminants necessarily requires pre-treatments before its use. The removal of $\mathrm{CO}_{2}$ and water, firstly, would increase the Wobbe Index ${ }^{1}$ as well as reduce some of the adverse effects associated with acid gas, etc. However, the presence of contaminants and other species requires various pre-treatment units ${ }^{2}$ (Brunetti et al., 2015; Vrbová and Ciahotný, 2017; Falbo et al., 2014; Falbo et al., 2016), including a

${ }^{1} \mathrm{https} / / /$ sciencing.com/calculate-wobbe-index-5147506.html

${ }^{2} \mathrm{http} / / /$ www.sepuran.com/product/sepuran/en/biogas-upgrading/ 
chiller for condensation and removal of water vapor, scrubbers for removal of $\mathrm{H}_{2} \mathrm{~S}$, mercaptans, halogenated organics, etc., and an activated carbon adsorption unit for siloxanes, VFA, etc. However, their load is quite relevant and strictly linked with the stability and durability of membranes in a gas separation unit and to the specification for grid injection. Moreover, all mentioned classical pre-treatment steps generate significant operating costs and problematic and un-reusable wastes (the exhausted carbon materials, solvents including the related additives, etc.).

Membrane operations are well-consolidated and today are used for various applications, thanks to the undoubted advantages with respect to other technologies, including modular design, a very low number of moving parts, robust design, smaller footprints, and continuous steady-state operation. During the last 5 years, the use of membrane separation technology in biogas upgrading has also been increased from 92 plants in 2015 to 173 plants in 2019. The use of membranes in biogas treatment is mostly limited to the upgrading of already pre-treated biogas to obtain biomethane.

This perspective highlights an innovative approach where biogas is not only seen as a source of methane, but also as a source of valuable compounds such as VOCs/VFA, and water vapor, which can be recovered in the logic of circular economy and minimization of wastes. The traditional process for biogas upgrading is thus replaced with an integrated membrane process where membranes are used not only for biomethane separation, but also as an alternative to reduce the number/size of or replace pre-treatment units.

\section{CURRENT ADVANCES IN BIOGAS UPGRADING}

Biogas is produced by the anaerobic fermentation of organic wastes coming from agriculture, municipal residues, and sewage sludge. Anaerobic digestion consists of four steps: hydrolysis, acidogenesis, acetogenesis, and methanogenesis (Denac et al., 1988; Kashyap et al., 2003). In the first stage, complex organic compounds (carbohydrates, lipids, proteins) are converted into simple compounds such as carboxylic volatile acids, ketones, alcohols, simple sugar, $\mathrm{H}_{2}$, and $\mathrm{CO}_{2}$ by enzymes. During acidogenesis and acetogenesis, these simple compounds are mainly transformed into acetic and formic acid. In the last stage, methanogenesis, acetic acid, $\mathrm{CO}_{2}$, and $\mathrm{H}_{2}$ are converted into $\mathrm{CH}_{4}$ and $\mathrm{CO}_{2}$. The main constituents of biogas are methane, carbon dioxide, and water vapor. However, other species are present in low quantity, such as nitrogen, oxygen, hydrogen sulfide, ammonia, hydrocarbons, and siloxanes. Depending on the nature of the treated biomass, its composition can vary; a typical composition range is reported in a previous study (Angelidaki et al., 2018). The presence of contaminants such as $\mathrm{H}_{2} \mathrm{~S}$ and $\mathrm{NH}_{3}$ provokes important problems of corrosion and toxicity. Carbon dioxide is also undesired since it provokes corrosion in the pipeline but the main issue is that it drastically reduces the calorific value of biogas owing to its high concentration in the raw stream (about 40\%). Siloxanes

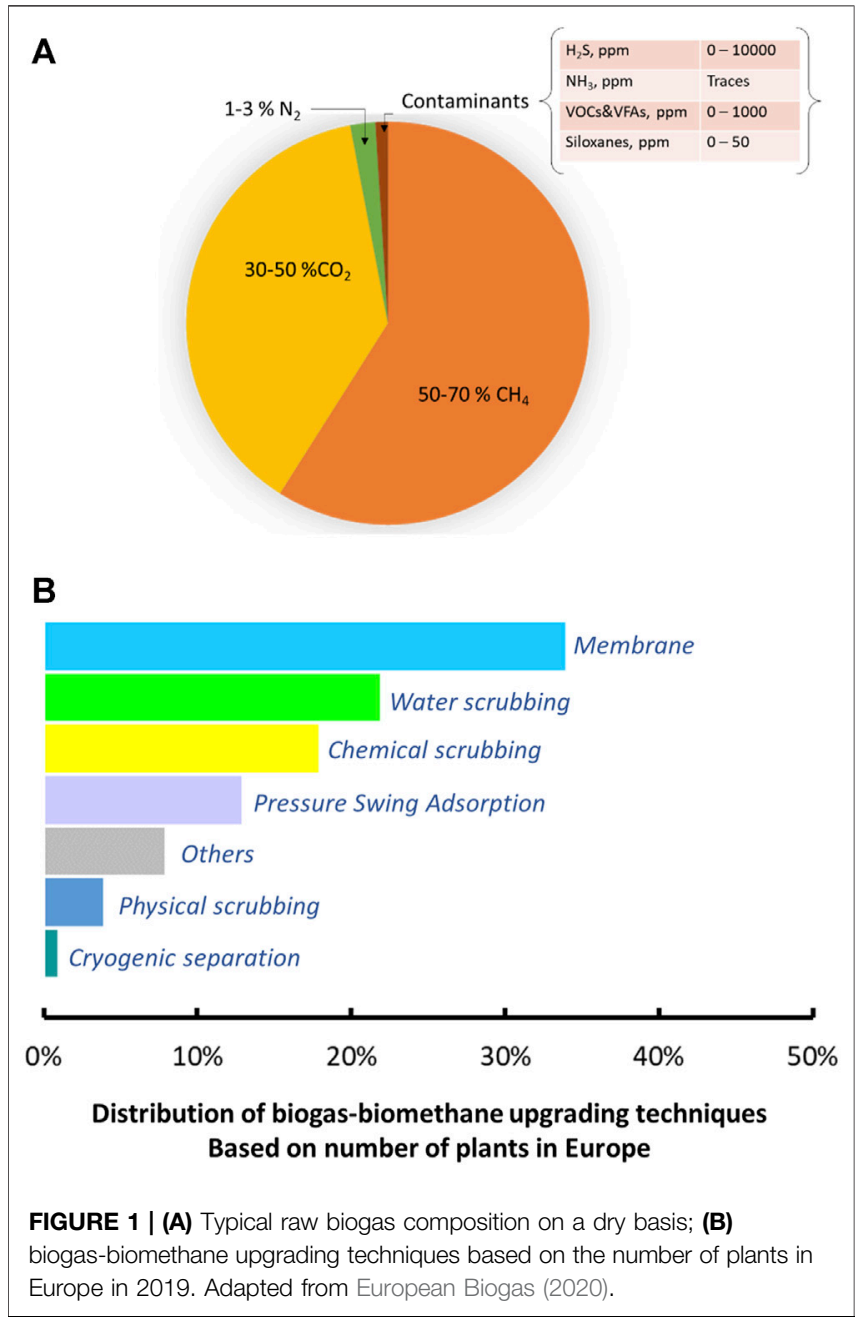

can cause abrasion owing to its silica deposition on metallic surfaces (Chen et al., 2015). All the contaminants reduce the calorific value of biogas and, thus, lower its energy content from about $36 \mathrm{MJ} / \mathrm{m}^{3}$ of pure $\mathrm{CH}_{4}$ to $20-25 \mathrm{MJ} / \mathrm{m}^{3}$ (Angelidaki et al., 2018).

Being produced from organic matter, biogas and biomethane are forms of renewable energy, which belong to the "short carbon cycle" (EBA, 2020). This means that the emissions from biogas and biomethane combustion are fully compensated upstream by photosynthesis. Moreover, being partly produced from waste or manure, biomethane allows us to reduce or avoid greenhouse gas emissions related to waste management, moving toward a "negative carbon footprint." A recent study of JRC (Joint Research Centre) ${ }^{3}$ estimated up to $240 \%$ for biogas production and up to $202 \%$ for biomethane production of GHG savings compared to EU fossil fuels.

This biogas is mostly used for renewable electricity production, followed by heat production and use as a

${ }^{3}$ https://publications.jrc.ec.europa.eu/repository/bitstream/JRC104759/ ld1a27215enn.pdf 
transport fuel. In addition, biogas has a good potential for grid balancing, either for electricity or natural gas grids, allowing the integration of higher shares of variable renewable energy sources, such as solar and wind, in the electricity grid. Biogas finds application as a thermal energy source to give hot water and steam by combustion, as fuel in vehicles, or in reforming to produce hydrogen for fuel cells (Van Herle et al., 2004; Papadias et al., 2012; Iulianelli et al., 2015). Biogas production in Europe is around $170 \mathrm{TWh} /$ year while biomethane production volumes are rapidly growing, with around 23 TWh produced in 2018 corresponding to about $12 \%$ of the total biogas. The progressive shift for producing biomethane from dedicated energy crops to waste and residue feedstocks is inducing a biomethane cost reduction, which actually ranges between $€ 50 / \mathrm{MWh}$ and $€ 90 / \mathrm{MWh}\left(\sim € 0.50 / \mathrm{m}^{3}-€ 0.90 / \mathrm{m}^{3}\right)$, depending on feedstock used and the size of the digester. Currently, around $90 \%$ of biomethane plants in the EU are connected to the gas grid with an injection increased up to approximately $20 \mathrm{TWh}$ per year in Europe, resulting in a $0.4 \%$ share in the gas network, with higher ratios in some countries (European Biogas, 2020). This share is expected to further increase to $5-8 \%$ (on average) by 2030 based on European and national targets, with differing shares among EU member states. A key aspect for further promoting biomethane utilization is the reduction of costs related to its purification and upgrading to the targets required for the grid.

\section{Contaminants}

Raw biogas exiting from biodigester is always water-saturated and contains a large number of contaminants in considerably smaller volumes together with the methane (Figure 1A) (Andriani et al., 2014; Salihu and Alam, 2015). These contaminants can cause operating problems in the plant itself (corrosion, etc.), during use of the clean gas if they are transported with the gas, and can also pose a risk to health and the environment. Among these contaminants, biogas can contain many VOCs, which are potentially harmful to humans or the environment. Depending on the type of biogas and organic matter used, the concentration of these contaminants can vary significantly. In most of the cases, the dominant VOCs are hydrocarbons (alkanes, aromatic hydrocarbons, cycloalkanes, terpenes), oxygenated hydrocarbons (alcohols and ketones), and halogenated hydrocarbons. In addition to VOCs, biogas can contain siloxanes (chemical compounds containing silicon, oxygen, and methyl groups), sulfur compounds, ammonia, or halogenated substances. Siloxanes were indicated as being characteristic for biogas from treatment plants, while terpenes occur in biogases from green waste. Hydrogen sulfide is the most commonly occurring sulfur compound in landfill gas, although mercaptans, disulfides, etc. may also occur. The hydrogen sulfide content is normally lower than $100 \mathrm{ppm}$ at typical landfill sites, but this figure may exceed $1,000 \mathrm{ppm}$. Under some specific conditions, particularly when acidogenesis prevails on methanogenesis, VFAs can be formed. This type of acid, produced by hydrolytic and acidifying bacteria during digestion, is chemically represented by the formula (R-COOH), where $\mathrm{R}$ is an alkyl group of the type $\mathrm{CH}_{3}\left(\mathrm{CH}_{2}\right)_{n}$, containing up to three carbon atoms. The level of their concentration is generally expressed in terms of acetic acid or COD depending on the type of substrate treated, and varies from about 200 to $2000 \mathrm{mg}$ per liter (Atasoy et al., 2018).

\section{Membrane Technology for Biogas Treatment and Upgrading}

In 2018, almost $12 \%$ of the biogas produced in Europe was upgraded to biomethane. The technologies for the upgrading of biogas to biomethane can be essentially distinguished on the basis of their separation mechanism, e.g., adsorption, absorption, separation with membranes (Khan et al., 2021). Among the various alternatives, water scrubbing and membrane separation are the most cost-effective techniques while chemical scrubbing offers relatively high biomethane purities with less $\mathrm{CH}_{4}$ losses (Katariya and Patolia, 2021). Historically, water scrubbing was preferred because of the simplicity of this operation. However, during the last decade, membrane separation stood out owing to its promising economic viability with investment costs of $3,500-7,500 € /\left(\mathrm{m}^{3} / \mathrm{h}\right)$ and operational costs of $7.5-12.5 € /\left(\mathrm{m}^{3} /\right.$ h) (Baena-Moreno et al., 2020).

In particular, membrane separation had a rapid growth passing from less than $5 \%$ in 2011 to $34 \%$ of total biomethane plants in 2019, whose number has grown in turn since 2011. It is followed by water and chemical scrubbing, which together upgrade around $56 \%$ of the European biomethane (European Biogas, 2020) (Figure 1B).

The main reason for this rapid growth is mainly related to the inherent advantages offered by membrane technology with respect to the other conventional separation methods. Membrane technology has a rapid response to variations and an extremely short start-up time. It is highly capable of maintaining product purity even though the feed flow rate to be treated is reduced down to $10 \%$ of that considered in the initial design. This can be done by maintaining the same stage cut, thus by either reducing feed pressure, increasing permeate pressure, or by using only some of the membrane modules which constitute the separation stage, isolating some others. Membrane systems are extremely reliable with respect to the on-stream factors (that is the possible unscheduled shutdown of the system that can be induced, for example, by malfunction or block of one or more valves or sensors that belong to the separation unit), owing to the few control components and the continuous mode operation, which imply the response to unscheduled shutdowns is extremely rapid. Their high modularity leads to a very easy expansion capability, since this only requires the addition of identical modules (Brunetti et al., 2010).

In addition, in the last few years, there has been a lot of progress in material development, leading to new membranes with very interesting $\mathrm{CO}_{2} / \mathrm{CH}_{4}$ separation performance (BaenaMoreno et al., 2020). Different polymeric materials have been adopted such as polyimide, cellulose acetate, polysulfone, polyethersulfone, and polycarbonates polydimethylsiloxane (Zhang et al., 2013; Chen et al., 2015). Among them, polyimide and cellulose acetate have been mainly used for $\mathrm{CO}_{2} / \mathrm{CH}_{4}$ separation at the commercial level. Actually, the 
current $\mathrm{CO}_{2}$ separation membrane technology is principally based on polymeric membranes owing to their low cost, excellent mechanical stability at high pressure, easy formability to flat sheets and hollow fibers, and scalability (Han and Ho, 2021). Significant progresses have also been reached in the development of inorganic membranes (zeolites, carbon molecular sieve, etc.), and carbon membranes resulted in a very cost-effective solution for upgrading biogas in small-scale plants up to $1,000 \mathrm{~m}^{3}$ (STP) $\mathrm{h}^{-1}$ (He et al., 2018; He, 2021). However, there are still some hurdles on their resistance to impurities $\left(\mathrm{H}_{2} \mathrm{~S}, \mathrm{H}_{2} \mathrm{O}\right)$, reproducibility, and scalability, which limit their development on a larger scale.

Currently, the main suppliers of polymeric membranes for biogas separation worldwide are: Evonik ${ }^{4}$, Air Liquid Medal ${ }^{5}$, and UBE Membranes ${ }^{6}$ who supply polyimide membranes; MTR who supply polydimethylsiloxane ${ }^{7}$; Air products $^{8}$ and Airrane who supply polysulphone ${ }^{9}$; and W.R. Grace, UOP Separex, and Natco Cynara who supply cellulose acetate (Baker, 2002; Baker and Lokhandwala, 2008; Scholz et al., 2013).

\section{INTEGRATED MEMBRANE PLANT AS SUSTAINABLE PERSPECTIVE FOR BIOGAS VALORIZATION}

Nowadays, most efforts are focused on the upgrading of raw biogas to biomethane; this implies the introduction of various pre-treatment units to reduce or eliminate contaminants and remove water vapor before using the unit for the dedicated separation of biomethane from $\mathrm{CO}_{2}$. Nevertheless, very little attention has been dedicated to the possibility of not only removing but also recovering and reusing contaminants, water, etc. contained in the raw biogas. The application of innovative technologies for the pre-treatment of biogas would imply a significant reduction of emissions, which can be induced in internal waste recovery.

Reducing, recovering, and reusing waste is an essential element in achieving a circular economy in the EU, and the chemical sector plays a key role in enabling this. In this scenario, the use of integrated membrane systems as alternatives to traditional operations will aid in closing the loop within the chemical sector.

Biogas stream can easily change in composition, water content, temperature, etc. depending on the digester's operation. Before carrying out $\mathrm{CO}_{2} / \mathrm{CH}_{4}$ separation, various pre-treatment stages are used to preserve the separation unit and also to meet the specifications for grid injection. These pre-treatments can be different depending on the $\mathrm{CO}_{2} / \mathrm{CH}_{4}$

${ }^{4}$ https://corporate.evonik.com/en/we-turn-biowaste-into-green-energy-115603. html

${ }^{5}$ https://www.airliquideadvancedseparations.com/sites/medal/files/2016/11/28/ alas_ng_brochure_final.pdf

${ }^{6}$ https://ube.es/products/gas-separation-membrane/

${ }^{7}$ https://www.mtrinc.com/our-business/natural-gas/biogas-co2-removal/

${ }^{8}$ https://www.airproducts.com/supply-modes/prism-membranes\#/

${ }^{9} \mathrm{http}: / /$ www.airrane.com/ separation technique. In the case this latter stage is based on membranes gas separation, the presence of contaminants such as $\mathrm{H}_{2} \mathrm{~S}, \mathrm{NH}_{3}$, siloxanes, and water can affect the performance of membranes or even damage them, etc. In the current plants for biomethane upgrading, which include membranes for $\mathrm{CO}_{2} /$ $\mathrm{CH}_{4}$ separation, the raw stream exiting from the biodigester is treated to remove humidity and contaminants (gas conditioning and $\mathrm{H}_{2} \mathrm{~S}$ removal units (Bauer et al., 2013), as shown in Figure 2B. These pre-treatments are usually based on chillers or condensers for water vapor condensation and scrubbers with $\mathrm{Fe}_{2} \mathrm{O}_{3}$ solutions for $\mathrm{H}_{2} \mathrm{~S}$ absorption (Basu et al., 2010; Angelidaki et al., 2019). The last pre-treatment unit is typically an activated carbon adsorption column for removing siloxanes, VOCs, VFA, etc. (Basu et al., 2010; Elwell et al., 2018; Tansel and Surita, 2019). Lastly, a suitable membrane stage is used for the selective permeation of $\mathrm{CO}_{2}$, whereas methane is concentrated in the retentate stream.

An interesting perspective that promotes "green process engineering" for industrial sustainable development (Drioli et al., 2012) has been recently introduced by the M-era.NET project called BioValue ${ }^{10}$. This project proposed the re-design of current biogas upgrading plants introducing membrane operations as pre-treatment and post-treatment units in the logic of also recovering other valuable compounds. BioValue's main scope is to pave the way towards the development of an innovative technology where membranes, used for separations, pre-treatments etc., will be the key enabling technology in redesigning the whole upgrading process. The new process operates along all the required steps, that is, pre-treatments for water and "pollutants" recovery as well gas separation of biomethane. "Pollutants" become resources and will no longer be wastes.

The integrated process includes three membrane operations:

- A membrane condenser as an innovative pre-treatment unit of the bio-digester gaseous stream for the removal of contaminants, water, and eventually valuable compounds. This unit splits the main stream into a dehydrated and purified gaseous stream mainly containing $\mathrm{CO}_{2}$ and $\mathrm{CH}_{4}$ and a liquid stream containing water, contaminants, VFA, VOCs, etc.

- A membrane gas separation unit for biomethane purification at the grid level.

- A microfiltration/ultrafiltration unit for pre-concentrating the condensate stream coming out of the membrane condenser, in order to have water on one side and a concentrated stream of VOCs/VFA on the other side.

- A pervaporation unit for VFA/VOCs concentration and, eventually, VFA/VOCs fractionation.

A membrane condenser is a new unit operation recently introduced for recovering the water vapor contained in waste gaseous (aeriforms) streams (Brunetti et al., 2013; Brunetti et al., 2019; Brunetti et al., 2020). Thanks to the presence of

${ }^{10} \mathrm{https} / /$ www.meranet-biovalue.com 


\section{A \\ Membrane-based Integrated Process}

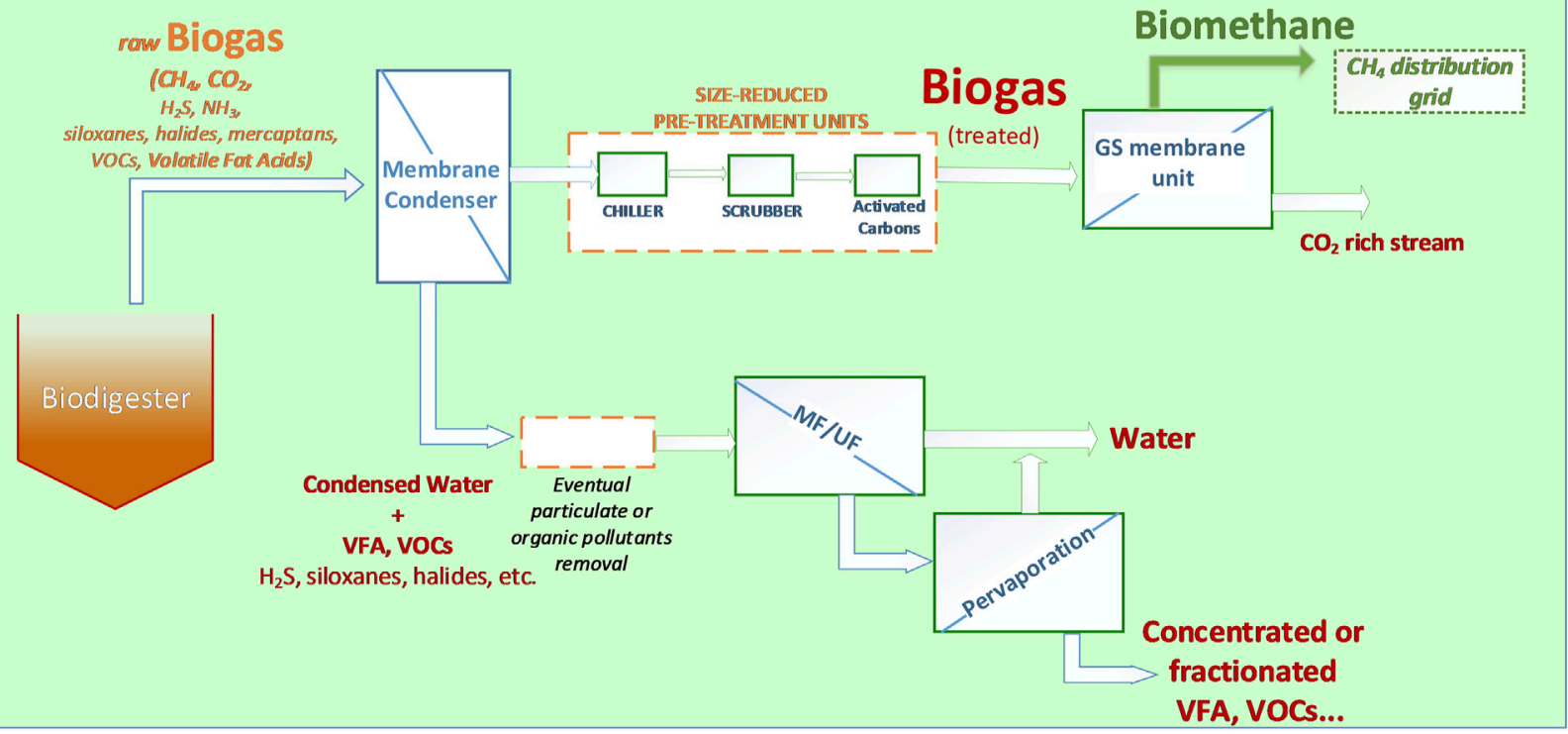

B

TRADITIONAL PROCESS

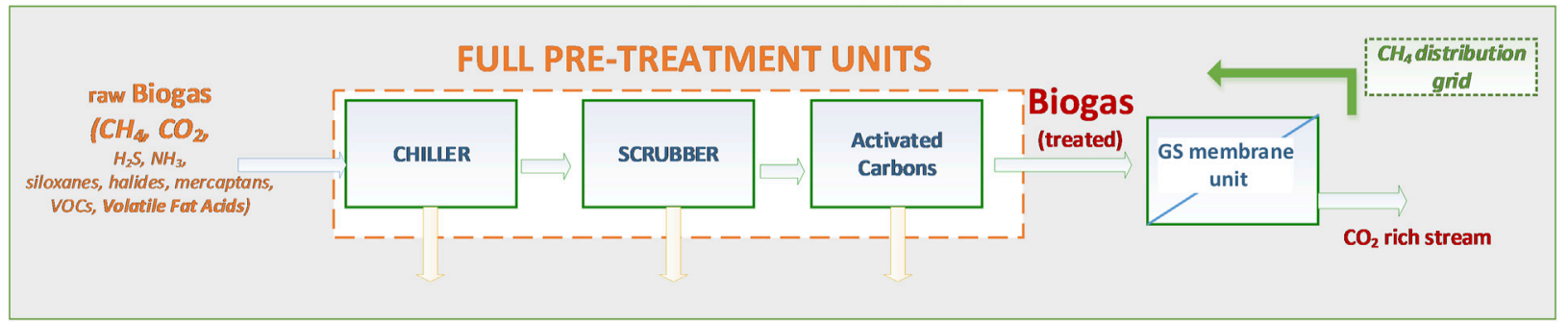

FIGURE 2 | Process schemes for biogas upgrading to biomethane, (A) integrated membrane process; (B) traditional process. Adapted from (https://www. meranet-biovalue.com)

microporous hydrophobic membranes and under a temperature difference between the feed stream and the membrane module, the water vapor contained in the aeriform feed stream can be condensed and recovered on the retentate side of the membrane module, whereas the partially dehydrated gases pass through the membrane in the permeate side. The tuning of contact time between the saturated stream and active membrane area as well as the control of temperature, will determine the fraction of water vapor that will condense. By exploiting the solubility of some contaminants such as $\mathrm{H}_{2} \mathrm{~S}, \mathrm{NH}_{3}$, etc. in the water vapor, part of the contaminants contained in the biogas feed stream can be retained in condensed water. In the presence of species such as VOCs or VFA, which in most cases are insoluble in water, their condensation will be driven by the temperature difference. The use of a membrane condenser is expected to reduce the number and/or the size of conventional pre-treatment units before the gas separation stage. In the meantime, the use of innovative membranes with higher tolerance towards $\mathrm{H}_{2} \mathrm{O}, \mathrm{H}_{2} \mathrm{~S}$, and other contaminants will allow us to lower the separation loads of conventional pre-treatment units.

The condensed water can then be further treated for separating the contaminants and/or VOCs and VFA. A dedicated MF/UF unit will allow us to concentrate the condensate recovering water which can be reused in the same plant and a concentrated stream of VFA and or VOCs. This latter stream could be further concentrated by mean of hydrophobic pervaporation, making use of the volatility of the VOC and VFA fraction, then followed by an organophilic pervaporation for fractionation of VOC/VFA. However, this latter perspective is highly speculative given the currently unsolvable limitations of such technologies (Essalhi and Khayet, 2015; Figoli et al., 2018).

The recovery of the VFA and VOCs dragged in the biogas stream can increase the diversification of the process, as they are valuable chemical compounds with diverse uses in the market that move from being building blocks of various organic compounds including alcohols, aldehydes, ketones, 
TABLE 1 | How the integrated membrane process can fit the main sustainability pillars.

\section{Sustainability Pillar}

Climate Action, Environment, Resource Efficiency and Raw

Materials

Waste reduction and recovery

Exploitation of sustainable carbon resources

Water treatment and recovery
Smart cities and circular economy

Water treatment and recovery
Integrated membrane process

advantage
The integrated membrane process acts in the direction of mitigating environmental issues being based on a zero-carbon process as well as in the maximization of resource efficiency and raw materials recovery Waste can provide raw materials. The integrated membrane prototype where the synergy of the membrane operations allows the recovery of resources such as biomethane, water, VOCs, VFA, Sulphur compounds and significant reduction of wastes, tending to reduce size/number of the pre-treatment stages moves toward this direction

The integrated membrane process pursues the development of a sustainable technology based on advanced membrane operations that allow the biomethane purification and at the same time the recovery of a $\mathrm{CO}_{2}$ rich stream, which can be then used for other purposes

Unconventional sources of water, which have not been widely used, are now increasingly considered as important sources also including gas humidity condensation. The integrated membrane process includes a "tailor-made" solution based on the use of membrane condenser, which allows the water recovery from biogas

The reduction, recovery and re-use of waste achievable by the use of an integrated membrane process significantly contribute in achieving a circular economy. In the conventional pre-treatment units, huge quantity of sorbents or active carbons are required to treat a raw biogas stream. After each cycle, these materials need to be regenerated before being used again. In the case of membranes operations, membrane is a separating interphase and its used size depends on the flow rate of the stream to be treated. The same membrane (or, in other words, the same amount of "materials") can treat a huge feed stream without requiring regeneration. Occasionally, it can be "cleaned/restored" and reutilized. Membranes move in the direction of a circular economy with significantly reduction of material/energy consumption and maximization of resources reuse esters, and olefins to several other biotechnological applications.

An additional positive aspect of this process can be profitability. According to the recent report published by the European Biogas Association, there are already more than 15,000 biogas plants in Europe, and this number is continuing to grow (EBA, 2021). Most biogas production is currently based on sewage sludge; however, it is estimated that by 2030, an increasing amount of biogas (about 224 TWh) will be produced from wet manure, landfill, undigested sewage sludge, and food-processing residues. For example, the desulphurization of biogas containing about $800 \mathrm{ppm}$ of $\mathrm{H}_{2} \mathrm{~S}$ generates additional operating costs approximatively/ca. $0.02 € / \mathrm{Nm}^{3}$ of biomethane, which could correspond to $5-10 \%$ of the total OPEX depending on the capacity. Removing or replacing desulphurization will significantly improve the overall upgrading costs. Apart from the economic benefits related to biomethane recovery and purification and to the reduction of pre-treatment stages, other benefits can be related to water and high added value compound recovery. Based on very preliminary calculations, the price of liquid water recovered with the membrane condenser ranges between $0.5-2 € / \mathrm{m}^{3}$ (considering costs related to energy requirements and membrane modules). This price fluctuates depending on the final estimated use and is very competitive where the average water price is high. A membrane condenser will also improve operating costs because it replaces the chiller unit consuming approximatively $0.1 \mathrm{kWh} / \mathrm{Nm}^{3}$ of biomethane, which is $10-20 \%$ of the total electricity consumption of the actual biogas upgrader. This contribution represents an OPEX improvement by a reduction $0.01-0.02 € / \mathrm{Nm}^{3}$. To put things into perspective, the biogas industry in EU could collectively save around 250 million $\mathrm{m}^{3}$ of water (assuming a modest $20 \%$ recovery), which can be used for other scopes with a positive impact on groundwater sources, in excellent agreement with the European Water Framework Directive.

Apart from the economic profitability, an important aspect that needs to be considered is the sustainability of the new process proposed. Looking at the SusChem-Strategic Innovation and Research Agenda ${ }^{11}$, the use of an integrated membrane system for biogas upgrading fits well with the various pillars of sustainability, as seen in Table 1.

\section{REMARKS AND FUTURE PERSPECTIVES}

The development of an integrated membrane process for biogas upgrading follows the path traced by various initiatives promoted at the EU level ${ }^{12}$ in making renewable gas and resource recovery maximization the core of the next energy future. The integration of a set of innovative technologies paves the way for the development of breakthrough membrane-based integrated plants for biomethane purification and at the same time waste recovery in valuable compounds (e.g., VFA) and water vapor, scaling back any pre-treatments. This objective can be concretized by following two main lines: first, through the combination and integration of advanced membrane operations able to overcome the current limitations of conventional technologies, second, through the development of

\footnotetext{
${ }^{11} \mathrm{http}: / /$ suschem.org

${ }^{12}$ https://www.gasforclimate2050.eu/who-we-are
} 
novel multifunctional materials with optimized separation properties that are able to withstand aggressive environments. The process here proposed for biogas treatment might also be extended to other (waste) gaseous streams such as biomass gasification and chemical and petrochemical plants as the challenges of the process and the advantages of the novel approach are similar.

\section{DATA AVAILABILITY STATEMENT}

The raw data supporting the conclusion of this article will be made available by the authors, without undue reservation.

\section{REFERENCES}

Andriani, D., Wresta, A., Atmaja, T. D., and Saepudin, A. (2014). A Review on Optimization Production and Upgrading Biogas through CO2 Removal Using Various Techniques. Appl. Biochem. Biotechnol. 172, 1909-1928. doi:10.1007/ s12010-013-0652-x

Angelidaki, I., Treu, L., Tsapekos, P., Luo, G., Campanaro, S., Wenzel, H., et al. (2018). Biogas Upgrading and Utilization: Current Status and Perspectives. Biotechnol. Adv. 36, 452-466. doi:10.1016/j.biotechadv.2018.01.011

Angelidaki, I., Xie, L., Luo, G., Zhang, Y., Oechsner, H., Lemmer, A., et al. (2019). Chapter 33 in Biofuels: Alternative Feedstocks and Conversion Processes for the Production of Liquid and Gaseous Biofuels. Second Edition. Elsevier IOnc., 817-843. doi:10.1016/b978-0-12-816856-1.00033-6

Atasoy, M., Owusu-Agyeman, I., Plaza, E., and Cetecioglu, Z. (2018). Bio-based Volatile Fatty Acid Production and Recovery from Waste Streams: Current Status and Future Challenges. Bioresour. Tech. 268, 773-786. doi:10.1016/ j.biortech.2018.07.042

Baena-Moreno, F. M., le Saché, E., Pastor-Pérez, L., and Reina, T. R. (2020). Membrane-based Technologies for Biogas Upgrading: a Review. Environ. Chem. Lett. 18, 1649-1658. doi:10.1007/s10311-020-01036-3

Baker, R. W. (2002). Future Directions of Membrane Gas Separation Technology. Ind. Eng. Chem. Res. 41, 1393-1411. doi:10.1021/ie0108088

Baker, R. W., and Lokhandwala, K. (2008). Natural Gas Processing with Membranes: an Overview. Ind. Eng. Chem. Res. 47, 2109-2121. doi:10.1021/ie071083w

Basu, S., Khan, A. L., Cano-Odena, A., Liu, C., and Vankelecom, I. F. J. (2010). Membrane-based Technologies for Biogas Separations. Chem. Soc. Rev. 39, 750-768. doi:10.1039/b817050a

Bauer, F., Persson, T., Hulteberg, C., and Tamm, D. (2013). Biogas Upgrading Technology Overview, Comparison and Perspectives for the Future. Biofuels, Bioprod. Bioref 7, 499-511. doi:10.1002/bbb.1423

Brunetti, A., Macedonio, F., Barbieri, G., and Drioli, E. (2019). Membrane Condenser as Emerging Technology for Water Recovery and Environment protection: Perspectives and Potentialities. BMC Chemical EngineeringSpringer Nature, 1-19.

Brunetti, A., Macedonio, F., Cui, Z., and Drioli, E. (2020). Membrane Condenser as Efficient Pre-treatment Unit for the Abatement of Particulate Contained in Waste Gaseous Streams. J. Environ. Chem. Eng. 8, 104353. doi:10.1016/j.jece.2020.104353

Brunetti, A., Santoro, S., Macedonio, F., Figoli, A., Drioli, E., and Barbieri, G. (2013). Waste Gaseous Streams: from Environmental Issue to Source of Water by Using Membrane Condensers, Clean-Soil. Air, Water 41 (9999), 1-9.

Brunetti, A., Scura, F., Barbieri, G., and Drioli, E. (2010). Membrane Technologies for CO2 Separation. J. Membr. Sci. 359, 115-125. doi:10.1016/ j.memsci.2009.11.040

Brunetti, A., Sun, Y., Caravella, A., Drioli, E., and Barbieri, G. (2015). Process Intensification for Greenhouse Gas Separation from Biogas: More Efficient Process Schemes Based on Membrane-Integrated Systems. Int. J. Greenhouse Gas Control. 35, 18-29. doi:10.1016/j.ijggc.2015.01.021

Chen, X. Y., Vinh-Thang, H., Ramirez, A. A., Rodrigue, D., and Kaliaguine, S. (2015). Membrane Gas Separation Technologies for Biogas Upgrading. RSC Adv. 5, 24399-24448. doi:10.1039/c5ra00666j

\section{AUTHOR CONTRIBUTIONS}

All authors listed have made a substantial, direct, and intellectual contribution to the work and approved it for publication.

\section{FUNDING}

The project BIOVALUE "Advanced Membranes for biogas upgrading and high added value compounds recovery," cofunded by the Regione Calabria in the framework of M-era.NET 2018 is gratefully acknowledged for supporting this research.

Denac, M., Miguel, A., and Dunn, I. J. (1988). Modeling Dynamic Experiments on the Anaerobic Degradation of Molasses Wastewater. Biotechnol. Bioeng. 31, 1-10. doi:10.1002/bit.260310102

Drioli, E., Brunetti, A., Di Profio, G., and Barbieri, G. (2012). Process Intensification Strategies and Membrane Engineering. Green. Chem. 14, 1561-1572. doi:10.1039/c2gc16668b

EBA (2021). European Biogas Association. Biogas. Available at: http://europeanbiogas.eu/biogas/(Accessed September 6, 2021).

EBA (2020). The Contribution of the Biogas and Biomethane Industries to Medium-Term Greenhouse Gas Reduction Targets and Climate-Neutrality by 2050. Background paper. Available at: https://www.europeanbiogas.eu/wpcontent/uploads/2020/04/20200419-Background-paper_final.pdf (Accessed September 6, 2021).

Elwell, A. C., Elsayed, N. H., Kuhn, J. N., and Joseph, B. (2018). Design and Analysis of Siloxanes Removal by Adsorption from Landfill Gas for WasteTo-Energy Processes. Waste Manag. 73, 189-196. doi:10.1016/ j.wasman.2017.12.021

Essalhi, M., and Khayet, M. (2015). "Fundamentals of Membrane Distillation," in Pervaporation, Vapour Permeation and Membrane Distillation (Amsterdam, Netherlands: Woodhead Publishing), 277-316. doi:10.1016/b978-1-78242-2464.00010-6

European Biogas (2020). Market State and Trends in Renewable and Low-Carbon Gases in Europe, A Gas Climate Report. Available at: https://www. europeanbiogas.eu/market-state-and-trends-in-renewable-and-low-carbongases-in-europe/(Accessed September 6, 2021).

Falbo, F., Brunetti, A., Barbieri, G., Drioli, E., and Tasselli, F. (2016). CO2/CH4 Separation by Means of Matrimid Hollow Fibre Membranes. Appl. Petrochem Res. 6 (4), 439-450. doi:10.1007/s13203-016-0164-z

Falbo, F., Tasselli, F., Brunetti, A., Drioli, E., and Barbieri, G. (2014). Polyimide Hollow Fiber Membranes for CO2 Separation from Wet Gas Mixtures. Braz. J. Chem. Eng. 31, 1023-1034. doi:10.1590/0104-6632.20140314s00003031

Figoli, A., Marino, T., Galiano, F., Blasi, E., Belsito, E. L., Liguori, A., et al. (2018). Potentiality of Polymeric Membranes in Aromatherapy: Application to Bergamot Essential Oil. Sep. Purif. Tech. 207, 166-178. doi:10.1016/ j.seppur.2018.05.065

Han, Y., and Ho, W. (2021). Polymeric Membranes for $\mathrm{CO}_{2}$ Separation and Capture. J. Membr. Sci. 628, 119244. doi:10.1016/j.memsci.2021.119244

He, X. (2021). A Novel Hybrid Digestion-Gasification Process Integrated with Membranes for Efficient Conversion of Biomass to Bio-Alcohols. Green. Energ. Environ. 6, 15-21. doi:10.1016/j.gee.2020.04.003

He, X., Chu, Y., Lindbråthen, A., Hillestad, M., and Hägg, M.-B. (2018). Carbon Molecular Sieve Membranes for Biogas Upgrading: Techno-Economic Feasibility Analysis. J. Clean. Prod. 194, 584-593. doi:10.1016/j.jclepro.2018.05.172

IRENA (2018). Global Energy Transformation: A Roadmap to 2050 (2018 Edition). Abu Dhabi: International Renewable Energy Agency. Available at: https://www. irena.org/publications/2018/Apr/Global-Energy-Transition-A-Roadmap-to2050 (Accessed May 12, 2021).

Iulianelli, A., Liguori, S., Huang, Y., and Basile, A. (2015). Model Biogas Steam Reforming in a Thin Pd-Supported Membrane Reactor to Generate Clean Hydrogen for Fuel Cells. J. Power Sourc. 273, 25-32. doi:10.1016/ j.jpowsour.2014.09.058 
Kapoor, R., Ghosh, P., Kumar, M., and Vijay, V. K. (2019). Evaluation of Biogas Upgrading Technologies and Future Perspectives: a Review. Environ. Sci. Pollut. Res. 26, 11631-11661. doi:10.1007/s11356-019-04767-1

Kárászová, M., Sedláková, Z., and Izák, P. (2015). Gas Permeation Processes in Biogas Upgrading: a Short Review. Chem. Pap. 69, 1277-1283. doi:10.1515/chempap-2015-0141

Kashyap, D. R., Dadhich, K. S., and Sharma, S. K. (2003). Biomethanation under Psychrophilic Conditions: a Review. Bioresour. Tech. 87, 147-153. doi:10.1016/ s0960-8524(02)00205-5

Katariya, H. G., and Patolia, H. P. (2021). Advances in Biogas Cleaning, Enrichment, and Utilization Technologies: A Way Forward. Biomass Conv. Bioref (Germany: Springer-Verlag GmbH).

Khan, M. U., Lee, J. T. E., Bashir, M. A., Dissanayake, P. D., Ok, Y. S., Tong, Y. W., et al. (2021). Current Status of Biogas Upgrading for Direct Biomethane Use: a Review. Renew. Sust. Energ. Rev. 149, 111343. doi:10.1016/j.rser.2021.111343

Maroneze, M. M., Zepka, L. Q., Vieira, J. G., Queiroz, M. I., and Jacob-Lopes, E. (2014). Production and Use of Biogas in Europe: a Survey of Current Status and Perspectives. Rev. Ambient E Agua 9, 445-458.

Papadias, D. D., Ahmed, S., and Kumar, R. (2012). Fuel Quality Issues with Biogas Energy - an Economic Analysis for a Stationary Fuel Cell System. Energy 44, 257-277. doi:10.1016/j.energy.2012.06.031

Salihu, A., and Alam, M. Z. (2015). Upgrading Strategies for Effective Utilization of Biogas. Environ. Prog. Sust. Energ. 34 (5), 1512-1520. doi:10.1002/ep.12117

Scholz, M., Melin, T., and Wessling, M. (2013). Transforming Biogas into Biomethane Using Membrane Technology. Renew. Sust. Energ. Rev. 17, 199-212. doi:10.1016/j.rser.2012.08.009

Tansel, B., and Surita, S. C. (2019). Managing Siloxanes in Biogas-To-Energy Facilities: Economic Comparison of Pre- vs post-combustion Practices. Waste Manag. 96, 121-127. doi:10.1016/j.wasman.2019.07.019
Van Herle, J., Membrez, Y., and Bucheli, O. (2004). Biogas as a Fuel Source for SOFC Co-generators. J. Power Sourc. 127, 300-312. doi:10.1016/ j.jpowsour.2003.09.027

Vrbová, V., and Ciahotný, K. (2017). Upgrading Biogas to Biomethane Using Membrane Separation. Energy Fuels 31 (9), 9393-9401. doi:10.1021/ acs.energyfuels.7b00120

Weiland, P. (2010). Biogas Production: Current State and Perspectives. Appl. Microbiol. Biotechnol. 85, 849-860. doi:10.1007/s00253-009-2246-7

Zhang, Y., Sunarso, J., Liu, S., and Wang, R. (2013). Current Status and Development of Membranes for $\mathrm{CO} 2 / \mathrm{CH} 4$ Separation: A Review. Int. J. Greenhouse Gas Control. 12, 84-107. doi:10.1016/j.ijggc.2012.10.009

Conflict of Interest: The authors declare that the research was conducted in the absence of any commercial or financial relationships that could be construed as a potential conflict of interest.

Publisher's Note: All claims expressed in this article are solely those of the authors and do not necessarily represent those of their affiliated organizations, or those of the publisher, the editors and the reviewers. Any product that may be evaluated in this article, or claim that may be made by its manufacturer, is not guaranteed or endorsed by the publisher.

Copyright (C) 2021 Brunetti and Barbieri. This is an open-access article distributed under the terms of the Creative Commons Attribution License (CC BY). The use, distribution or reproduction in other forums is permitted, provided the original author(s) and the copyright owner(s) are credited and that the original publication in this journal is cited, in accordance with accepted academic practice. No use, distribution or reproduction is permitted which does not comply with these terms. 